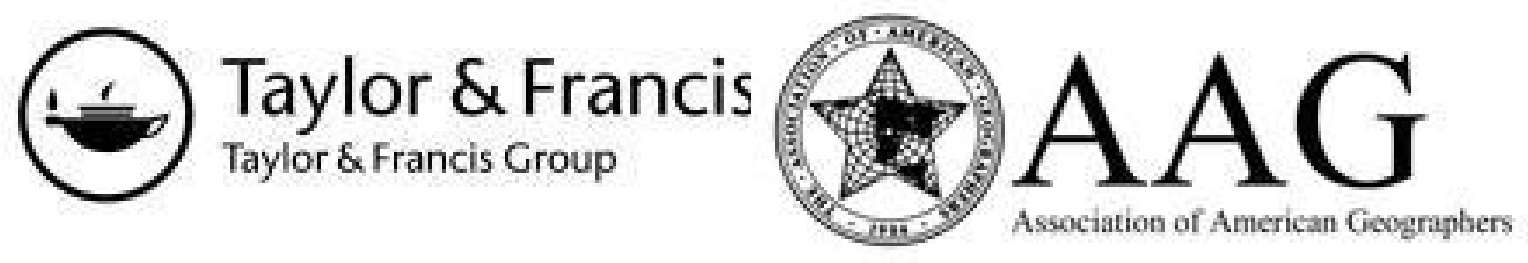

A Geographical Pilgrimage from Ireland to Italy

Author(s): W. M. Davis

Source: Annals of the Association of American Geographers, Vol. 2 (1912), pp. 73-100

Published by: Taylor \& Francis, Ltd. on behalf of the Association of American Geographers

Stable URL: http://www.jstor.org/stable/2560643

Accessed: 27-06-2016 03:32 UTC

Your use of the JSTOR archive indicates your acceptance of the Terms \& Conditions of Use, available at

http://about.jstor.org/terms

JSTOR is a not-for-profit service that helps scholars, researchers, and students discover, use, and build upon a wide range of content in a trusted digital archive. We use information technology and tools to increase productivity and facilitate new forms of scholarship. For more information about JSTOR, please contact support@jstor.org.

Taylor \& Francis, Ltd., Association of American Geographers are collaborating with JSTOR to digitize, preserve and extend access to Annals of the Association of American Geographers 


\title{
A GEOGRAPHICAL PILGRIMAGE FROM IRELAND TO ITALY
}

\author{
W. M. DAVIS
}

CONTENTS

Page

The pilgrimage of 1911 and its members.................... 73

Five days in Ireland................................. 75

A concise description of southwestern Ireland.................. 76

A week in Wales..................................... 78

The even upland at Lands End........................... 80

Marine denudation and subaerial degradation................... 81

The sea cliffs of Cornwall............................... 82

A round-about-explanation. . ............................. 83

The uplands of Devonshire-Cornwall....................... 84

The rarity of cliffs of decreasing height...................... 85

The south coast of England............................... 86

The island of Jersey................................. 87

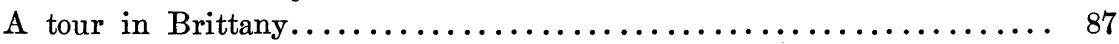

The thing called a Skiou................................. 89

A visit to the Limousin................................ 91

The volcanic district of Auvergne......................... 92

The Morvan of central France............................. 93

Other morvans. . ..................................... 94

Morvans and mendips.................................. 95

The valley of the Armançon................................ 95

The Jura Mountains.................................. 96

Overdeepened valleys in the Alps......................... 97

Lake Maggiore. . ................................. 99

The Pilrimage of 1911 and its Members.-The following pages describe an excursion which began in southern Ireland on August 1, and disbanded in northern Italy on October 5, 1911. It took the name of "Pilgrimage" because we visited many localities made famous in the history of physical geography by the work of masters in an earlier generation. The members of the Pilgrimage, of whom a list here follows, numbered thirty-two and represented fourteen countries, England, Scotland, Ireland and Wales being counted separately. Seldom did our party include more than ten of the total membership. Several student members are marked (St.).

H. O. Beckit, School of Geography, Oxford University, England.

Léon Boutry, University of Clermont-Ferrand, France.

Maurice Brienne, University of Lille, France. (St.)

Abel Briquet, Douai, France. 
G. G. Chisholm, University of Edinburgh, Scotland.

G. A. J. Cole, Royal College of Science, Dublin, Ireland.

J. Cvijic, University of Belgrade, Servia.

James Cossar, Training College, Glasgow, Scotland.

W. M. Davis, Harvard University, Cambridge, Mass.

Pierre Denis, University of Paris, France.

Albert Demangeon, University of Lille, France.

Lucien Gallois, University of Paris, France.

Gilbert Garde, University of Clermont-Ferrand, France.

$\mathrm{Ph}$. Glangeaud, University of Clermont-Ferrand, France.

Walter Hanns, University of Leipzig, Germany. (St.)

Amund Helland, University of Christiania, Norway.

Mark Jefferson, State Normal College, Ypsilanti, Mich.

O. T. Jones, University College, Aberystwyth, Wales.

Olinto Marinelli, Institute of Higher Studies, Florence, Italy.

J. E. Marr, Cambridge University, Cambridge, England.

Fritz Nussbaum, University of Bern, Switzerland.

Hans Praesent, University of Greifswald, Germany.

Giuseppe Ricchieri, Scientific and Literary Academy, Milan, Italy.

Alfred Rühl, University of Marburg, Germany.

Iudomir v. Sawicki, University of Cracow, Galicia.

Hans Spethmann, University of Berlin, Germany.

Aubrey Strahan, Geological Survey of Great Britain, London.

Antoine Vacher, University of Rennes, France.

Harry Waldbaur, University of Leipzig, Germany.

W. B. Wright, Geological Survey, Dublin, Ireland.

Fritz Wyss, University of Bern, Switzerland. (St.)

Naomasa Yamasaki, University of Tokio, Japan.

There was abundant discussion directed to the origin of the land forms in the districts visited, and to the best means of describing them; but, as is usually the case when geographers are gathered together, many diverse opinions and methods were developed. Even the object and scope of our work were differently interpreted by the various members. Nevertheless there was a general acceptance of explanatory in preference to empirical methods for geographical descriptions; and frequent employment was made of the scheme of "structure, process and stage" for the description of land forms, though with greatly varying proficiency and completeness. There was an interesting diversity of opinion in such problems as the origin of certain truncated uplands which we visited, some members ascribing them to marine denudation, others to subaerial degradation; hence this problem is discussed with some fullness on a later page. Frequent dissent was expressed from my principle, that geological formationnames, indicative only of geological dates in past time, ought to be 
excluded from purely geographical descriptions, since geography has to do only with the present. Some of the liveliest discussions arose when comparisons were made of one-page descriptions of a limited area that we had examined together; the order of the statement and the emphasis given to different elements varied greatly, in spite of the fact that we had all seen the same things. All this shows how far we are still from having standardized our geographical methods.

Five Days in Iremand.-The pilgrims gathered under the valued guidance of G. A. J. Cole, Professor of Geology in the Royal College of Science, Dublin, and Director of the Geological Survey of Ireland, with whom we first examined some interesting features of glacial origin in the neighborhood of Killarney, among which were: the Gap of Dunloe, a good example of a "glacial distributary pass" in Sölch's classification-that is, one in which glacial overflow across a preglacial notch has shifted the crest of the notch up the glacial stream and at the same time lowered it; a well defined glacial amphitheater where the glacial distributary which deepened Dunloe gap ended on the plain to the north; and a beautiful example of a shore-terrace formed in the waters of a glacial-marginal lake which had its outlet at the head of the valley that it occupied-all these features being under investigation by Mr. Wright.

Then the great sea cliffs at the west end of Valencia Island were visited, where we admired the contrast between the normally rounded and soil covered forms of the landward mountain slopes and the sharply undercut precipices by which their seaward faces were characterized. From the top of these cliffs the sharpened peaks of the Skelligs were seen; they once presumably had rounded forms, but they have been so strongly undercut all around the shore line by the violent attack of the Atlantic waves that they are now steepened to the very summit. By no means all the length of the coast in the southwest possesses lofty cliffs; they occur only where the subrecent submergence of the lowlands, in the retreating border of which ragged cliffs of small height are cut, has been sufficient to bring the sea to the base of a group of subdued mountains. It was interesting to note that all the mountains were of complex anticlinal structure, while the lowland belts between them were deeply eroded synclines; thus contradicting the assertion often made that in greatly denuded folded structures, the synclines remain in relief, and showing that relief is more dependent on rock resistance than on folds.

Returning eastward we stopped at the elbow of the Blackwater, where Jukes, just fifty years before, first gave correct explanation to the relation of transverse and longitudinal, that is of consequent and subsequent, streams and valleys in tilted structures of varying resistance. This explanation was for a number of years overlooked 
by observers in the United States, to the serious detriment of their work. We finally visited the ragged cliffs of the southern coast, where the successive development of cove, cave and slip appeared to be the regular order of progress in the vigorous attack of the sea on this immature coast line. Good exercise was found at the end of these few days in Ireland in attempting to compress an explanatory physiographic description of the district we had seen into as few words as possible; advantage being taken of a final day in Dublin to look up Jukes' famous article "On the Mode of Formation of Some River Valleys in the South of Ireland."1 "One of the experiments resulted as follows:

A Concise Description of Southwestern Ireland.-The heavy sedimentary strata of southwestern Ireland-the district referred to lies between Waterford on the east and Dingle Bay on the west-

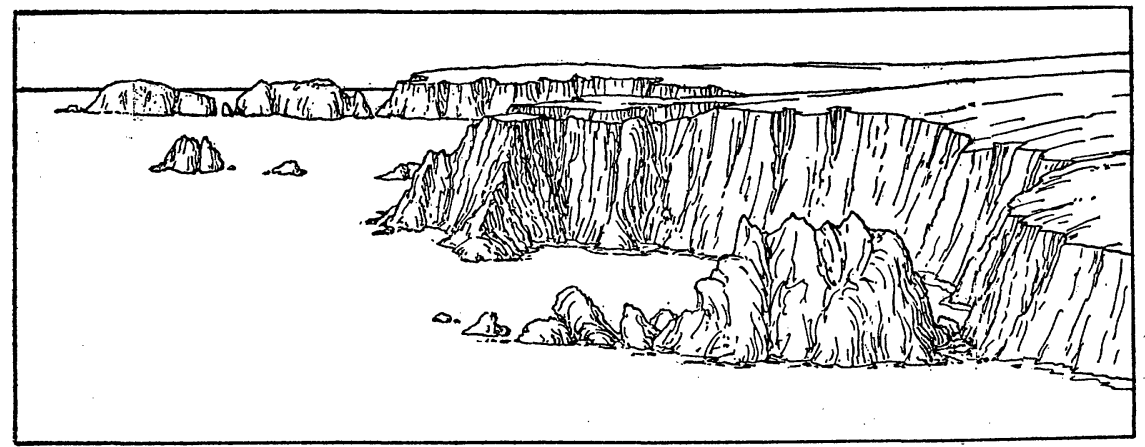

Frg. 1.-Sea cliffs near Great Newtown Head, about two miles west of Tramore, South Coast of Ireland, looking west.

were long ago compressed into complex folds trending north of east and south of west, and the region was then eroded to a late stage of the cycle thus introduced. The resulting lowlands, with numerous residual ranges and monadnocks which usually followed anticlines of resistant sandstones, were moderately uplifted with a gentle slant to the south; whereupon the synclines of limestone and slate were broadly excavated forming open rolling lowlands from three to ten miles wide and leaving the truncated anticlines and their surmounting residuals of the earlier cycle in discontinuous belts of irregularly dissected uplands and mountains. Some of the lowlands are trenched as if renewed uplift had revived their streams. The well adjusted drainage consists of transverse streams which cut through the uplands in narrow valleys and longitudinal streams which wander rather irregularly along the lowlands, receiving many branches from insequent ravines in adjoining higher belts.

${ }^{1}$ Quart. Journ. Geol. Soc., XVIII, 1862. 
In the western part of the district the sandstones seem to be more resistant, as several complex anticlinal belts there remained in stronger relief at the close of the earlier cycle; they now, since the later uplift, have altitudes of from fifteen hundred to three thousand feet, with subdued forms of coarse texture, except where glaciated, as further stated below. The uplands and lowlands are nearly everywhere covered with a veneer of till that was formed in a widespread glaciation, and not with soil of local origin. Later local glaciation in the higher mountains excavated valley-head cwms, above which some of the crests are craggy; overdeepened the larger valleys within the ranges, thus producing oversteepened, plucked and scoured valley sides; and sometimes formed morainic amphitheaters on the piedmont lowlands, fronted with outwashed gravels, and more or less trenched and terraced. There are many cascades that fall from the highlands

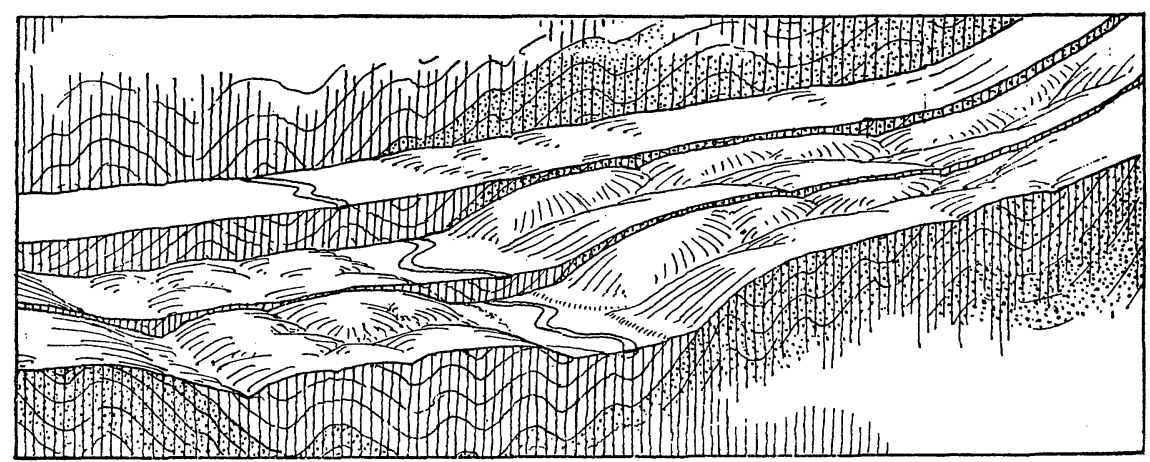

FIG. 2.-Scheme of development for mountains, uplands and valleys of southern Ireland, looking northwest. First cycle, a peneplain interrupted by subdued mountains of the most resistant rocks in axes of anticlines; second cycle, excavation of broad valley lowlands along synclinal belts of limestone and contemporaneous submature dissection of uplands; third cycle, erosion of mature valleys in former lowland belts.

into the cwms and from the cwms and hanging side-valleys into the main valley troughs; while the main streams on the trough floors are often broken by rapids. Lakes of small size or bogs representing former lakes, are common in the cwms; lakes occur also in the valley troughs and morainic amphitheaters, the best known of the latter kind being those of Killarney.

A depression of the region has led the sea into the distal parts of many valleys, thus forming the narrow transverse bays of the southern coast, of which the best known example is Cork harbor, and the wider longitudinal bays between the mountainous promontories of the southwestern coast, of which Dingle, Kenmare and Bantry are the largest. Very little wave work has yet been done on the inner shoreline of the bays; they are particularly irregular where the land 
surface has been plucked and scoured by recent glaciation. The exposed outer coast has been cut back into ragged cliffs by the stormy sea; the cliffs being of moderate height where cut in the lowlands, but rising a thousand feet where the higher mountains have been attacked. Some of the subdued monadnocks of the earlier cycle, later converted

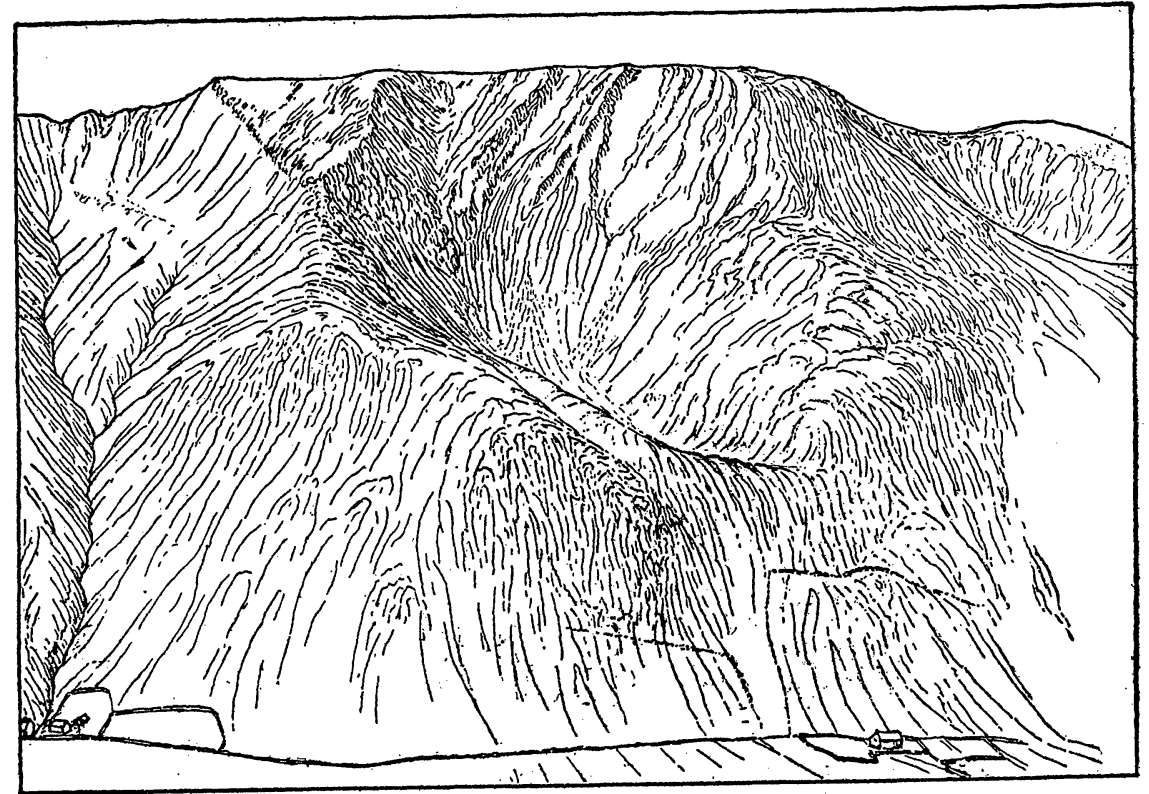

FIG. 3.-A cwm in the side of the glaciated trough of Nant Francon (Beaver valley) near Bethesda, Wales; looking south. The rocks are steeply inclined slates, sandstones and lavas.

into islands, have now been transformed into sharp peaks by "circumabrasion."

A Week IN WALes.-Our next rendezvous was at Bethesda in North Wales, where a number of new members were gathered from England, Scotland, France, Germany, Norway, Galicia and the United States. Here under the amiable leadership of Dr. J. E. Marr of Cambridge University, we studied the effects of glacial erosion in modifying the normally subdued preglacial mountain and valley forms of the Snowdon district. As was the case on the Italian lakes in the summer of 1908, we had to regret that no one was present to maintain from conviction the inefficiency of glaciers as eroding agencies. A day on Snowdon was greatly enjoyed; the contrast of the deeply excavated valley-head cwms with the normally rounded summit and spreading convex spurs was very impressive. On both sides of the Snowdon mass we saw fine examples of glacially overdeepened troughs, with hanging lateral valleys opening in the side walls and 
with rock steps and rock basins scoured in the floor. The lowering of preglacial passes by glacial cross-currents was noted at several points; the result in facilitating transportation through the mountains is here of evident economic importance on a small scale, as it is on a much larger scale along the line of the Canadian Pacific Railway across the Rocky Mountains and the Selkirks. As centers for the study of these typical features, Llanberis on the north and Snowdon Range on the southwest may be highly recommended.

Two half-days were profitably given, under the guidance of Professor O. T. Jones of the University College of Wales, to the uplands and highlands east of Aberystwyth, this being the region made classic by Ramsay's famous essay in which he brought forward his theory of the origin of certain plains by the marine denudation of moun-

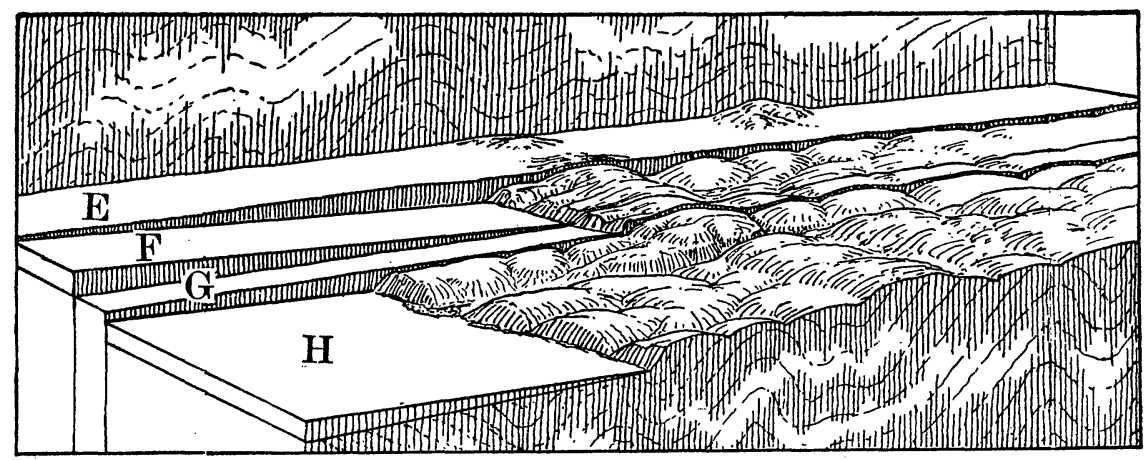

FIG. 4.-Scheme of development of highlands, uplands and coast line in westcentral Wales, near Aberystwith; looking northeast. First cycle E, an extensive lowland of normal erosion or of marine abrasion, with occasional residuals. Second cycle, F, normal dissection of uplifted plain and encroachment on margin by marine abrasion. Introduction of third cycle, $G$, by elevation and withdrawal of sea. Third cycle, $H$, dissection of land area and encroachment on uplifted plain of marine abrasion by renewed attack of the sea.

tains. It was here a pleasure to find that our guide had made a new attack on this old problem, and had recognized two uplifted and dissected plains, separated by an escarpment, where Ramsay had seen only one; and further that he had good reasons for explaining at least the lower uplands as the result of marine denudation, a process that has been too generally neglected by British students since their recognition of the great value of subaerial degradation. Professor Jones has prepared a chapter presenting his views on central Wales in a publication that is unfortunately not easily accessible. ${ }^{2}$

On the first of our two half-days in Central Wales we saw a re-

\footnotetext{
${ }^{2}$ Souvenir of the Aberyswith Conference (National Union of Teachers), 1911. Edited by John Ballinger. Published by the National Union of Teachers, Bolton House, Russell Square, London, W. C., 1911.
} 
markably fine example of a recent stream capture, about twelve miles inland from Aberystwith. The gorge down and up stream from the elbow is deep cut and steep sided; the side streams cascade on their descent into it, and the main stream at its bottom is not yet well graded. An excellent view up-stream (northward) across the elbow of capture is had from the railway station of Devil's Bridge, whence one may easily see the young gorge sharply cut in the mature valley floor.

The Even Upland of Lands End.-We left Wales for southern England, and on our way made an early morning visit to the incised meanders of the Wye, which like the uplands of Wales, are famous from Ramsay's early work. We went southward across Devonshire to Cornwall where the even upland near Lands End proved fruitful as a subject for explanatory description. Some regarded it as a plain of marine denudation; but the absence of cliffs on the exposed sides of several low monadnocks convinced the present writer that the upland was chiefly the result of subaerial normal erosion; although the occurrence of gravels containing marine fossils, reported by British observers, shows that the plain was submerged for a time after it had been worn down and before it was uplifted and dissected.

Let it here be explicitly stated that the discrimination between marine denudation and subaerial degradation in the production of the Lands End upland is rather a geological than a geographical problem, so long as it is concerned with the processes of past time. It becomes a truly geographical problem however, when it is shown that the present day forms of the surface would be of one kind if they had been formed by marine denudation, and of another kind if prepared by subaerial degradation; and still more geographical when the presentday forms of that interesting district are described in terms of the process by which it is believed they have been prepared. Of course the geological problem here touched is as worthy of attention from geologists as any other problem of past time; and it surely is open to investigation as a geological problem by geographers also, if they wish to investigate it; but geographers ought to recognize that this or any similar problem falls properly within their own province only when its solution is found to be helpful in describing things as they now exist.

In my own opinion the solution of this problem is geographically very helpful, because in my understanding of the case, plains of marine denudation and plains of subaerial degradation, uplifted and submaturely dissected, would not look alike, provided that the work done upon them before uplift had not gone so far as to wear all residual reliefs down to a featureless surface. The difference in appearance 
of the two kinds of plains may be made clear by the following considerations :

Marine Denudation and Subaerial Degradation.-These two processes must go on together, one on the seaward side and one on the landward side of a shifting shoreline; and the area of sea-cut plain must, so long as the land mass stands still, gain on the subaerial area. Furthermore, in order that the sea-cut plain may gain a width of ten or twenty miles, the retreat of the sea cliffs at its landward border must be more rapid, probably very much more rapid, than the degradation of the land area, as shown in Fig. 5. When both processes are far advanced, the line by which their areas are separated

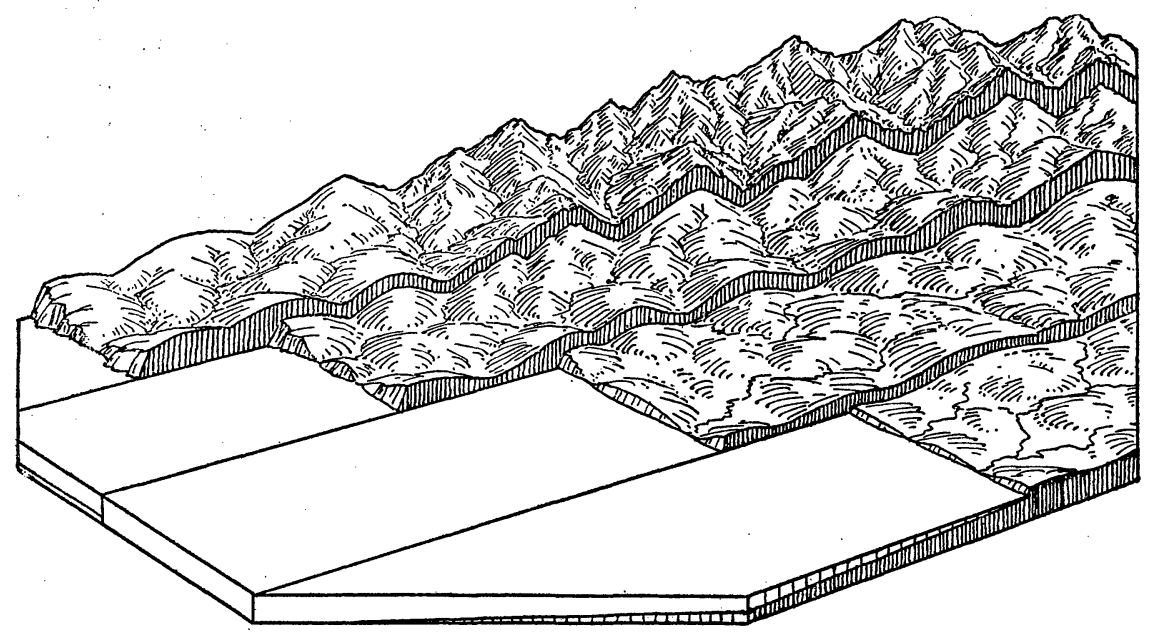

Fig. 5.-Relation of normal degradation to marine abrasion; the horizontal encroachment of the latter being five or ten times the downward wear of the former. Development of sea cliffs of decreasing height in the advanced stages of marine abrasion.

must be of relatively simple curvature, must be marked by low cliffs, and some of these cliffs must have been cut back of the low summit-arch of vanishing hills; consequently such cliffs may be described as of "decreasing height." A simple line of low cliffs, some of which are cliffs of decreasing height, is therefore an essential feature of the boundary between a so-far finished plain of marine denudation and a nearly finished plain of subaerial degradation, or peneplain. Hence this inferred line of cliffs may prove to be a valuable criterion in uplifted examples where the presence of massive rocks prevents discrimination by means of adjusted or unadjusted drainage lines. The boundary of an upland thus comes to have a value in determining its origin, and in giving it an explanatory description. 
The less advanced a cycle of subaerial erosion, the more distinct should be the line of cliffs by which its area is separated from that of an adjoining area of marine denudation. It was the occurrence of a line of cliffs at the inner border of the lower uplands in central Wales, very similar, except for battering by weather and ravining by streams, to the line of uneven cliffs by which the same uplands fall off to the plain of marine denudation now in progress of making by the sea, that persuaded Professor Jones of the marine planation of the upland; and it was the uncertainty as to the existence of such cliffs around the residual monadnocks which still surmount the inner highland that left his hearers in doubt as to the origin of that earlier developed and more uplifted area. (See Fig. 4.)

If a district is described by an observer as an uplifted and partly dissected plain of marine denudation, the reader of such a description ought to have the right to infer that the writer of it had, before he wrote about it, seen a simple cliff-line, more or less battered by weathering, along its inner border. If on the other hand a district is described as an uplifted and dissected peneplain, this term being chosen so as to imply the subaerial degradation of the district in question, the reader has the right to infer that such mounds or monadnocks as rise above the general level are not bordered on their exposed side by cliffs or scarps. In other words, as soon as the discrimination between the two processes here considered is made in terms of their visible products, it has a definite value in aiding the description of an existing landscape; and thus understood the discrimination fairly enters the list of geographical problems. This matter is here repeated at some length, because when it was discussed during our Pilgrimage, it appeared to be novel to some of our party.

The Sea Cliffs of Cornwall.-The fine sea cliffs which abruptly terminate the uplands about Lands End were apparently the work of two attacks of the waves; first a rather well advanced attack, during or after which the cliffs gained a graded slope; then a lately renewed and vigorous attack, by which the base of the graded cliffs is sharply undercut in ragged and rocky forms, the platform in front of them not being yet widened enough to hold a beach, except in the larger coves. The amount of loss suffered by the uplands during the total retreat of the sea cliffs was carefully considered. The generally accepted idea is that the uplands once had a much greater extension seaward, and that they have been reduced to their present area entirely by marine erosion; but if such were the case the present coast ought to have the simple outline of maturity, while as a matter of fact its outline is decidedly irregular and immature. This suggests a moderate recession, less than a mile, as the result of marine attack on a not distant initial shore line of distinct slope, instead of a great 
recession following an attack on a remote initial shore line where a gradual decline of the upland might lead it below. sea level. Two possible explanations for a neighboring initial shore line of distinct slope were offered. One accounted for it by a differential faulting of the region after peneplanation, so that the sea began its attack on the fault scarp that separated the upfaulted from the downfaulted areas; but as it would require many intersecting faults of sub-recent date to produce a scarp only a mile or so outside of the present irregular shoreline, and as no traces of such faults are found on the remaining upland, this suggestion was rejected. The alternative suggestion was as follows:

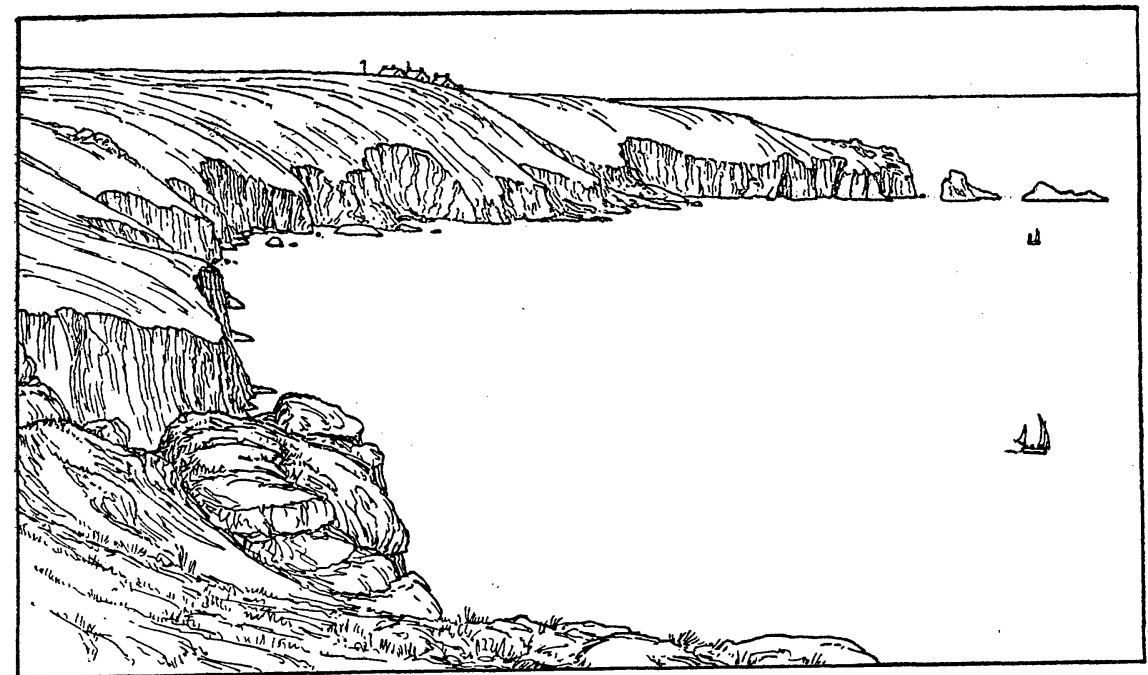

FIG. 6.-The sloping cliffs of the Lands End upland, and the new attack of the sea at their base; looking south.

A Round-about Explanation.-The deformed crystalline mass, of which Lands End and the greater part of Cornwall consists, was worn down to moderate relief, then depressed and buried under a heavy sedimentary cover; the compound mass was next unevenly uplifted and advanced to old age in the cycle of erosion thus introduced, so that the peneplain then formed traversed both the deformed older crystalline mass and the inclined strata of the sedimentary cover. The region was then rather evenly uplifted and the weaker covering strata were reduced to a new lowland or peneplain, while the resistant crystallines were only submaturely or maturely dissected; and in this condition the whole region was slightly depressed, so that the lowland of the new peneplain was submerged and the lower valleys in the dissected crystallines were drowned; thus the sea came to have its new shore 
line on the slope which separates the crystalline uplands from the drowned lowlands, this slope being nothing more than a part of the ancient worn-down land surface that had lately been laid bare by the stripping of the covering strata from it between the levels of the two peneplains. The irregularity of the slope, and hence also of the initial shore line that contoured in consequent fashion around it, would depend partly on the inequalities of the ancient land surface, partly on the unevenness of its uplift after burial; and a moderate recession of such a shore line would produce the existing irregular shore line with its immature cliffs.

Several facts may be cited in favor of this somewhat elaborate explanation. First, the eastern or landward border of the CornwallDevonshire upland is determined by an irregular slope where the crystalline rocks, long ago worn down to an uneven land surface, depressed, buried, and uplifted, have been, after the peneplanation which produced the even surface of the present uplands, again uplifted and laid bare around their border by the lower peneplanation of the weaker covering strata; that is, the uplands are here bordered by precisely such a definite but irregular slope as is postulated, in the explanation under discussion, for the initial north, west, and south borders of the uplands. No shore line follows the eastern border, because the depression after the newer peneplanation was not sufficient to submerge that part of the bordering lowland. Second, the valleys by which the uplands are submaturely or maturely dissected are now all drowned in their lower courses, and thus transformed into branching bays of most typical form, as may be seen near Falmouth and Plymouth.

A curious difficulty was met in the discussion of this explanation, which deserves to be placed on record. The explanation was difficult to talk about because the structural "thing" that it involved had no simple name by which it could be easily mentioned; it had to be paraphrased, and the paraphrasing by different pilgrims varied greatly according as they emphasized one element of the "thing" or another, with the result of inconsequence and misunderstandings. We soon came to feel the need of some convenient term by which the roundabout paraphrasing could be avoided; and of this more will be said later.

The Uplands of Devonshire and Cornwall.-During the coming and going on our southwestward detour, we made brief stops on the north Devon coast, where the broad, coarse-textured highlands of Exmore descend abruptly to the shore of the Bristol Channel; on the north and south borders of the central highland of Dartmoor, so far out of the way and empty that an artillery camp is on one side of it and a large prison on the other; and on one of the beautiful 
branching embayments that indent the southern coast,- the one that has Salcombe at its entrance and Kingsbridge at its head. After this brief inspection of the region it seemed to us all that its leading physiographical features could be concisely described as the products of two cycles of erosion on a disordered mass of crystalline rocks. The more even uplands of to-day, dissected by steep-sided valleys, are parts of the uplifted peneplain to which all but the most resistant rocks were reduced when the first cycle was interrupted by the uplift which introduced the second; while the large or small highland areas of broadly arched forms and coarse texture consist of the most resistant rocks, which therefore survived above the peneplain of the uplands as isolated or grouped monadnocks. On the other hand the districts of rolling hills with convex summits and with significant inequality of height, separated by well opened, late mature valleys, are areas of moderately resistant rocks, which were presumably worn to a smooth

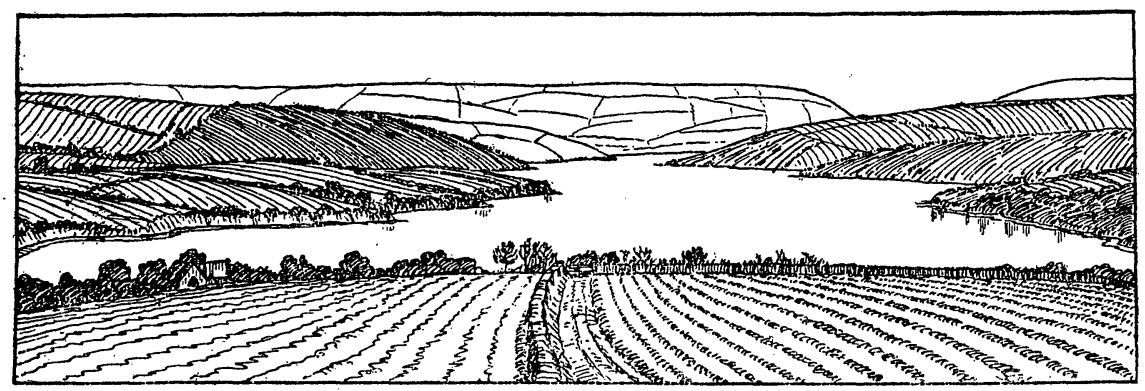

FIG. 7.-A branching embayment entering the valleys of the late-mature uplands of southern Devonshire; looking south from near Kingsbridge toward Salcombe.

plain at the close of the first cycle, and are now already advanced to a late mature stage of subdued forms in the recent cycle. If to this simple scheme, we add the conception of a bordering mass of weaker strata, now worn down to a new peneplain and recently submerged, as stated above, the chief features of the coast as well as of the interior may be understood. Some British observers have recognized levels of erosion or abrasion at several different altitudes, on which they base a more complicated scheme of morphogeny; but as far as our journey gave us a view of the region, the leading features are all referable to two cycles followed by a recent episode of slight submergence.

The Rarity of Cliffs of Decreasing Height.- In further evidence of the small retreat of the Devonshire-Cornwall coast, the rarity of cliffs of decreasing height deserves mention; that is of cliffs which have been, as above explained, cut back so far as to stand behind the broad crest of flat-topped hills into which the uplifted peneplain has 
been dissected, so that with further recession they must lose height as the inland slope of the hill is consumed. Such cliffs ought not to be uncommon along a shore line that has been cut far back of its initial outline; they ought to be very rare or absent along a shore line that has been cut back but a little, less than a mile. They are certainly rare in Cornwall. The only one we saw stands not far west of Plymouth where a valley, trending for a stretch almost parallel to the coast, lies exceptionally near it. The rarity of decreasing cliffs seems to be one of the strongest reasons for concluding that the Cornish coast has not yet suffered a great retreat.

It may perhaps be objected that, if the uplands of Devonshire-Cornwall had really been surrounded at a little distance outside of their present border by an inclined series of covering strata, some remnants of such strata ought somewhere to be found, either clinging to the present coast, or standing forth as small islands. If this objection is fair, then the postulate, that the basal members of the covering strata are weak must be incorrect. Now it does happen that along the southern part of the eastern border of the Devonshire uplands, the covering strata are red sandstones and conglomerates of sufficient strength to have as yet escaped the peneplanation that has already overtaken the weaker shales and marls farther north; hence to this extent the postulate that the covering strata are weak is not justified. The stronger sandstones rise in hills, some of which do cling to the uplands of crystalline rock, but these are exceptional. Fragments of the sandstones might be looked for on the sea floor along the southern coast. Since my return home, I have found that such fragments have been dredged south of Plymouth.*

The South Coast of England.-On leaving Devonshire we followed the south coast where it transects the middle and upper members of the heavy series of covering strata, dipping gently eastward, and hence overlying the weak basal members on which the lowland bordering the Devonshire uplands has been worn down. The middle and upper members, although stronger than the lower ones, are evidently less resistant than the crystalline mass of DevonshireCornwall, for their now isolated uplands are separated by many broadly opened, late mature valleys; and along the coast the uplands are evenly truncated by smooth cliffs with beaches at their bases, and the cliffs are all strung along a comparatively simple line. This shows a good advance toward maturity of the marine cycle as here developed, in contrast to its immaturity on the ragged coast of more resistant rocks in Cornwall.

* R. H. Worth, Journ. Marine Biol. Assoc. United Kingdom, V. 1897, 381-387; Ibid., VIII, 1908, 118-188. See also patches of sandstone along coast; Geol. Surv. Gr. Brit., sheets XX, XXI XXII, XXIII, XXIV, XXVI. 
It was interesting to note, as we crossed some of the uplands near the south coast, that they are covered with gravel; and this we took to indicate that the uplands are parts of a peneplain, presumably of the same peneplain which we had already seen better preserved in the uplands of crystalline rocks farther back. Local features of interest on the coast were the great landslips near Axmouth, the greater part of which occurred in 1839, described and figured by Conybeare; and the Chesil bank, a superb beach or reef of pebbles which stretches in a long sweeping curve from southeast to northwest, concave to the sea, and which attaches the former island of Portland to the mainland.

The IsLand of Jersey.-Weymouth harbor lies inside of the Chesil bank. There we took steamer to Jersey, and spent a profitable day walking over the well smoothed peneplain and along the fine cliffs of that tidy island. A broad platform of ragged rocks, laid bare on the southeast of the island when the strong tide ebbs, was a striking feature. There can be no question that, what with frequent storms and strong tidal currents, the abrasive action of the sea, always well supplied with gravel and sand, is intensely active on such a platform; and that the attack of the high-tide storm waves at the base of the cliffs is violently effective in cutting them back wherever they are reached. But violent as the marine action is here, we are not therefore constrained to conclude that a great recession of the cliffs and a great diminution in the area of the island have already resulted from it; for time, as well as violence, is a factor of this problem; and of the time that has elapsed since the island took its present attitude with respect to the sea, we are not well informed. In any case the irregularity of the shore line was such as to recall the inference we had made in Cornwall as to the small measure of the cliff retreat. Hence Jersey, and probably the other Channel islands as well, if explained in view of this inference, should not be regarded as small remnants much reduced by marine attack from a once large and continuous land area, but as moderately reduced masses of fundamental rocks, once surrounded and buried by covering strata, uplifted and peneplained; and then, after another uplift, left in relief by the relatively rapid downwearing of the weaker covering strata ; finally, after a recent and slight submergence of the surrounding lowlands, violently attacked by the sea and now moderately cut back from their then developed outlines. It would be convenient to have a name for small forms of this kind as well as for the larger ones.

A Tour in Brittany.-We crossed from Jersey to St. Malo in Brittany, and were there conducted by Professor Antoine Vacher, then of the University of Rennes, now of Lille, around a well chosen route, on which we saw an excellent variety of scenery. The northern uplands, submaturely dissected; had irregular sea cliffs and recențly sub- 
merged valleys. Cliffs of decreasing height were rare or absent. Hence, here again we found indications of a moderate measure of cliff retreat from an initial shore line produced by the transgression of the sea across a submerged lowland, until it stopped on the distinctly sloping border of an upland of more resistant rocks. Thus we felt for the third time the need of a more concise name for the total "thing" of which Brittany as well as Cornwall and Jersey was supposed to be the present phase.

A fine branching embayment of the northern coast served to locate the city of St. Brieuc, an excellent center for local excursions in this picturesque district. In view of the typical development of branching embayments, here as well. as on the other side of the Channel, it is

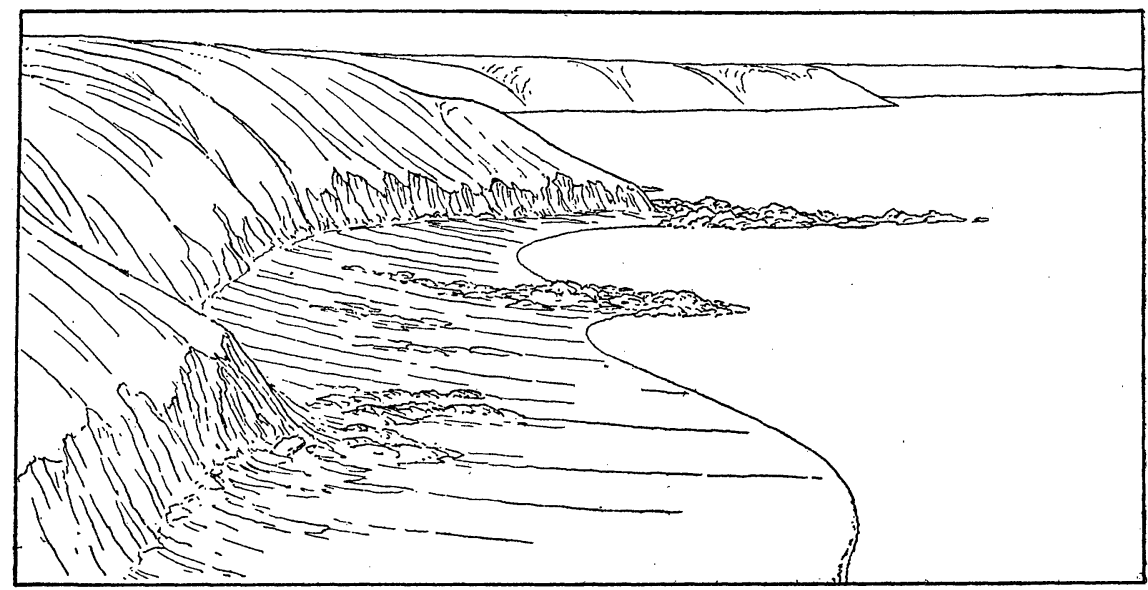

FIG. 8.-The sloping cliffs of the uplands of northern Brittany, undercut by young sea cliffs; near St. Brieuc, looking west.

singular that their simple explanation by the submergence of previously eroded valleys was not invented on these long-known coasts; and still more singular that, sixty years after its invention by Dana to account for the irregular sea-arms which he saw in certain Pacific islands when he was geologist of the Wilkes expedition, this simple explanation was still held to be in need of elementary elucidation when presented only a few years ago to the readers of the most scientific geographical journal published in France!

Farther west a south-north valley, deeply incised in a remarkably even part of the northern upland belt, demanded the construction of one of the loftiest viaducts on the line of an east-west railroad. We crossed the viaduct in the evening and looked down from it on the lights of Morlaix deep beneath on the valley floor. The next morning we admired the great viaduct of two-storied stone arches as we drove from the town up the valley on our way southward across country. 
Our route soon led us out of the valley over the even upland to its inner (southern) border, where it gradually passes into rolling hills of slowly increasing height. The transition is gradual and there is no sign of an ancient sea cliff; the transition seems to coincide with a change of rock resistance, of which the culmination was found in a long, high, narrow-crested ridge, following the east-west trend of a belt of vertical slates. Hence here, as in Cornwall, the upland was regarded as a subaerial peneplain, and not as a plain of marine denudation. The sharp-crested slate ridge is a part of the northern one of two east-westerly ribs by which the uplands of Brittany are divided into several belts. After descending from the northern rib, we crossed an intermediate upland belt near its western end; its surface there is rolling, but it is trenched by an incised meandering valley of remarkably perfect development. The river that cut this valley must have learned to meander before the beginning of the present cycle of erosion, even if the cycle in which its meanders were developed was interrupted before all the neighboring hills had been deduced to a plain.

Further progress southward took us through another rib to a southern upland. There we first turned westward to the extremity of one of the points that encloses the large bay at the western extremity of Brittany, a fine locality for the study of marine action on a dissected and partly submerged upland; then eastward to a middle part of the southern upland where it slopes to the sea and is transformed by submergence into a group of small islands, known as the Morbihan. Somewhat farther east we walked over the uplands where they are trenched by the transverse gorge of a south flowing river, the Vilaine; and afterwards following up this valley we came to a lowland excavated in an area of weak rocks within the central uplands. In this lowland lies the city of Rennes. During this delightful tour we found much confirmation of an impression that was formed during a shorter visit eleven years before; namely, that Brittany, like Devonshire-Cornwall, may be described chiefly in terms of two cycles of erosion; the first of which had reached an advanced stage when it was interrupted by the broad elevation which introduced the second; while the second reached a submature or mature stage when it suffered the slight and recent episode of depression, whereby the distal parts of the valleys were converted into little bays.

The Thing Called a "Skiov."-As we were leaving Brittany we noted from the passing train, with the aid of our geological maps, how the crystalline rocks of the uplands disappear under the covering strata which dip gently eastward into the Paris basin. Our talk again returned to the "thing" for which a name was wanted, here as well as in Devonshire, and then, as if losing patience over the delay of our paraphrasing, I exclaimed; "Let us call the thing a 


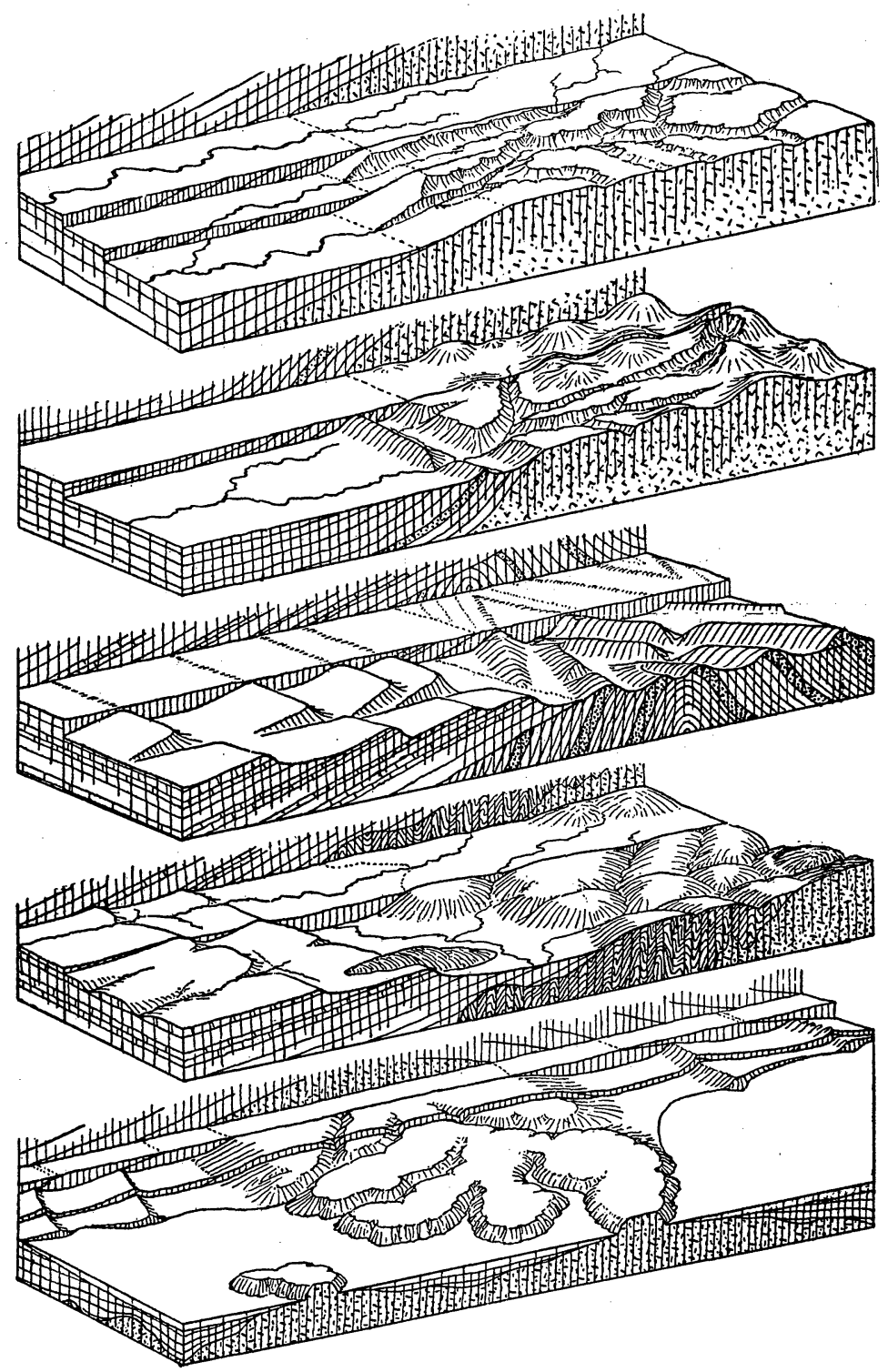

Fig. 9.-Five morvans. The first is the simplest example; its only special feature being a double uplift, resulting in two-cycle valleys in the hard-rock uplands: the angle of intersection between the two plains which truncate the hard-rock mass is small. The second has a larger angle between the two truncating surfaces of the hard-rock mass; the later surface is much interrupted by large monadnocks; and the higher valley-heads of the present cycle have been glaciated; a single monoclinal ridge rises from the lower plains near the mountain base. The third has for its older mass a body of stronger and weaker strata of folded structure, exhibiting Appalachian zigzags; while the overlying strata include four resistant members or cuesta makers, so grouped as to produce overlapping, close-set and open-spaced cuestas. The fourth has a mendip which interrupts the lowlands and indents the first cuesta. The fifth is a partly sea-girt morvan with a wholly sea-girt mendip near by. 
Skiou!" Not that Skiou was a word of orthodox entymology, for it has no more ancestry than "gas," but that its adoption would cut short all vain dispute as to the rival claims of Latin and Greek roots. From that time forward, Skiou was used in our daily discussions and was recorded in our note-books. One pilgrim even went so far as to draw a series of block diagrams, representing skious of different kinds, varying with the different values of its variable elements. The word was regarded only as a provisional or slang term which might serve until something better was found, as stated below.

A Visit то тhe Limousin.-Our next stop after Brittany was in a district of central France known as Limousin, which comprises the western part of the crystalline highlands; the eastern part where lavas become abundant being known as Auvergne. There we had the expert guidance of Albert Demangeon, then Professor of Geography at the University of Lille, now called to the University of Paris, who had the year before published an excellent article on this district. $\mathrm{He}$ showed it to consist of a rolling highland, sometimes smooth enough to be called a peneplain, above which rose a higher highland on which traces of a still earlier peneplain were detected, and beneath which valleys of later erosion were more or less sharply incised. An aberrant feature, west of the main body of the highlands, results from the occurrence of a body of weaker sedimentary strata, which had been faulted into the crystalline mass probably before the erosion of the higher highland, and which has now been broadly excavated to a late mature, in part to a nearly senile stage of low relief, in the same cycle of erosion as that in which the narrow valleys of the adjoining highland were incised. This lowland basin with its subdued hills is therefore one of the many illustrations of the much more rapid advance of weak structures through a cycle of erosion than of hard structures. In the lowland and because of its low relief, lies the city of Brives, the largest center of population in the district.

The crystalline highland and the weak-rock lowland are now separated by a well defined slope, nearly a thousand feet in descent, which seems to be a good example of a fault-line scarp; that is, of a scarp due to the action of erosion on a faulted mass in a later cycle than the one that was introduced by the faulting. During the earlier part of the later cycle the resistant rocks stand up while the weaker rocks are worn down, and the fault surface which separates them is thus revealed, more or less battered by weathering and notched by ravines. In the latter part of the cycle, when the highlands are worn down, then the fault-line scarp of course disappears. A fault-line scarp thus defined, should be distinguished from a fault scarp, which is initially due to displacement, and on which erosion acts from the beginning not to reveal the scarp but to obliterate it. 
The unsettled question that we discussed in the Limousin turned chiefly on the number of cycles of erosion which the features of the district exhibited, and which therefore ought to be mentioned in a geographical description. Some members recognized more cycles than did others; but all were agreed that it was desirable to phrase the description of the observed features in terms of the cycles of erosion that they have suffered, however many these may be; and also in terms of the stage of development that the successive cycles had reached when they were interrupted by the displacement which introduced the next cycle.

The Volcanic District of Auverane.-On leaving the Limousin and entering the Auvergne, we came under the enthusiastic leadership of Ph. Glangeaud, Professor of Geology of the University of Clermont-Ferrand. We ascended from a deep glacial trough eroded in the northern slope of the ancient volcano which culminates in the Puy de Sancy, and met our guide near the summit. From there, as well as from the Puy de Dôme farther east on a later day, he pointed out to us a great variety of most interesting features, among which were:- the rolling crystalline highland and the mature valleys eroded beneath it; the broad lowland plain known as the Limagne, excavated in a body of lacustrine sediments that are down-faulted next east of the crystalline highlands and separated from them by a fine fault-line scarp; young volcanoes, such as Puy Pariou with its perfect crater; dissected volcanoes, such as the Puy de Sancy and the larger Cantal to the south; young lava flows, ragged and barren, such as those which stretch from the symmetrical Puy Côme and which curiously obstruct the valley of the Sioule; or those from Pariou, which run down deep valleys in the eastern border of the highland and emerge on the lowland of the Limagne back of Clermont-Ferrand; and those which issued from a small volcano with a breached crater farther south and ran several miles down a valley to the southeast, barring a branch valley on the way and thus forming the picturesque Lac d'Aydat; more ancient lava flows, weathered and soil covered, along the side of which gorges have been eroded, so that the columnar structure of the lavas is visible; still more ancient flows now stretching evenly across the fault by which the crystalline mass is terminated and extending forward in table-mountains on an underpinning of weak lacustrine sediments which they protect from the erosion that has elsewhere swept them away; and other ancient flows now standing up in isolated mesas, often associated with volcanic necks, over the excavated plain of the Limagne, thus proving conclusively that the lacustrine sediments once rose to the level of the crystalline highlands 
on the west; and finally the oldest flow of all, which caps a low mound on the crystalline highlands. It was this last feature which suggested the only new point that our visit here brought forward; namely an attempt to correlate the beginning of volcanic activity in Auvergne with the cycles of erosion recognized by Professor Demangeon in the Limousin. The lava-capped crystalline mound, surmounting by fifty or more meters the general surface of the highland, indicated that the earliest eruption in Auvergne began before the end of the cycle in which the erosion of the broad highland, common to both provinces, was completed, and hence, before the elevation of the region to its present altitude.

No district that we visited was more replete with geographic interest than this classic ground of Auvergne, where Desmarest in the eighteeth century and Scrope in the nineteenth established so many fundamental principles on which our modern studies are based. It was noticeable, however, that although Auvergne has been minutely studied by geologists, it has not yet received geographical description in accordance with modern explanatory methods.

The Morvan of Central France.-The Morvan, a northeastern extension of the central highlands where our next halt was made, was especially interesting because of its well defined limitation on the east and west by fault-line scarps. Here once more we found a structure which might be called a skiou. So well indeed did it represent the essential features of an ideal type, that since then the local name, Morvan, has been proposed as a formal substitute for the provisional name which we used during the Pilgrimage. We, therefore, now intend to describe the uplands of Devonshire-Cornwall and of Brittany, and the highlands on the central plateau of France, as morvans, writing the word with a small $\mathrm{m}$, and pronouncing it for American use in our own fashion, as we do France and Paris.

The original Morvan may be described as a morvan in which the first wearing down of the crystalline foundation was advanced to senile planation, probably in part at least by the waves of an ancient sea; in which the covering strata are the marls and limestones of the Paris basin; in which the tilting of the compound mass was very slight, perhaps a few degrees only, to the northwest; in which the first truncation after tilting was well advanced even on the crystallines sometimes locally reaching planation, but more generally not having gone beyond peneplanation, and occasionally failing to obliterate subdued monadnocks, one or two hundred meters in relief; in which the next following uplift was accomplished in two phases, the first being followed by a pause long enough for the erosion of mature 
valleys in the crystalline area, and the second permitting the erosion of narrower young valleys of less depth in the distal parts of the mature valleys; in which the gently inclined covering strata on the north are so little eroded that the more resistant members still stand up, even crested and about as high as the Morvan highland, yet so much eroded that the weaker basal members are broadly excavated so as to produce a wide subsequent depression, enclosed by the inface of the first cuesta on one side and by the long stripped slope of the most ancient planation of the crystalline rocks on the other. On the east and west the highland is limited by fault-line scarps, as above stated; and on the south by a broad depression excavated on an obliquely transverse belt of down-folded or faulted weaker strata. The irregular rectangle thus defined measures about fifty kilometers on a side.

Other Morvans.-The uplands of Devonshire-Cornwall might now in their turn be described, following the explanation given for them above, as a morvan of irregular outline, measuring seventy. miles north and south by sixty miles east and west, with a tapering southwestward extension about fifty miles in length; normally limited on the east by a distinct but irregular slope which descends to the newer peneplain that has been worn down on the weaker covering strata; and supposed formerly to have been limited in the same way on the north, west and south; but on those sides now cliffed by the sea in consequence of a recent depression by which the presumable lowlands thereabouts have been submerged: hence this example is on three sides a sea-rimmed morvan.

The evident advantage of this style of description lies in the abundant meaning that is packed into the technical term, morvan, for if the reader already knows what the term means, a long general introductory description is cut out and the attention is at once turned to the special features which characterize the particular example under consideration. The term morvan may thus come to have in geography a value of the same kind, perhaps of the same degree, that is possessed by such a term as logarithm in mathematics. No mathematician would to-day delay his statement by presenting in paraphrase the somewhat elaborate meaning that is so conveniently packed into the single word logarithm; and so perhaps no geographer, fifty years hence, will embarrass himself and his readers by the long circumlocution that is required if morvan or some convenient term is not employed, when the thing that is meant by the term is to be considered.

If this scheme of description is followed further, one might say that the Front Range of the Rocky Mountains in Colorado is a long morvan, of which the crystalline mass was long ago worn down to 
a remarkably smooth surface, and buried under a heavy series of covering strata; that the compound mass was then bent in an eastfacing monoclinal flexure of great north-south extent, with a maximum dip of some thirty degrees, but that the flexure was sometimes ripped into a fault; that the truncation of the flexed mass produced a fairly good peneplain over large parts of the crystalline area, but left goodsized monadnocks standing singly or in groups; that after the later uplift the covering strata, already smoothly worn down a first time in the previous cycle, were again, because of the broad uplifting of the region, worn down to a plain of vast extent, except for a few monoclinal ridges near the mountain border; while the uplifted or up-arched peneplain of the crystalline rocks was only submaturely dissected, and in its higher valleys strongly glaciated, as has already been set forth without the use of the term morvan, in an earlier article in these Annals.

Morvans and Mendips.-Whether the island of Jersey should be described as a sea-rimmed morvan is doubtful; for so long as the inferred surrounding strata are invisible, it can not be determined whether the crystalline rocks of the island gained the height that they once possessed above the level of the upland peneplain by deformation after burial, as is implied in typical morvans, or whether the former height of the crystallines above the level of the upland peneplain was simply due to the mountainous relief of the fundamental surface before and during the deposition of the covering strata. A standard example of the latter relation in England is found in the Mendip hills, which rise through the covering strata east of Devonshire without deforming their moderate eastward dip; an equally good American example is seen in Baraboo Ridge south of the crystalline highlands of Wisconsin. The small size of the Channel Islands may be taken to indicate that they are more probably sea-girt mendips than sea-girt morvans.

The Valley of the Armangon.-A short detour was made to the northwest from the Morvan, so as to examine one of the larger consequent valleys - that of the Armançon, a member of the Seine systemby which the broadly truncated strata of the Paris basin are to-day incised. The few days spent there were profitable in discovering many details characteristic of a valley of this kind; the most notable of which are due to the occurrence of overlapping cuestas, that is, of cuestas separated by so narrow a subsequent lowland that the back slope of one cuesta descends into the mouth of each transverse valley that is eroded in the next. Another interesting detail is that the valley of the 
Armançon, which often has a rather direct course, must nevertheless have been carved by a meandering river; for its course is meandering wherever the resistant cuesta-making strata descend to the level of the valley floor. There the valley is not yet widened sufficiently to destroy the meandering form that presumably existed all along its length in an earlier stage of its erosion; but wherever the lower slope of the valley sides is occupied by weak strata, they waste easily and sap any harder strata that may overlie them. Hence, in these stretches the valley has already been so much widened that all traces of its earlier meanders are lost.

The occurrence here of several successive cuestas so close together that they overlap suggests the need of selected adjectives for the description of cuestas in terms of the distance that separates them. Thus we may speak of overlapping cuestas, as in the present case; of close-set cuestas, where the back slope of one, as it descends into the floor of a longitudinal valley, just reaches the inface of the next; and open-spaced cuestas, where a broad lowland is developed between the back slope of one and the inface of the next. The controlling factors for these three cases are chiefly the thickness of the several strata in the cuesta-making series, the dip of the series, the depth of the dissection, and the stage of erosion.

The Jura Mountains:-In the Jura Mountains we were met by Dr. Fritz Nussbaum of the University of Bern and Mr. Wyss, one of his students who was engaged in a special study of that district. We spent several days under their guidance in trying to determine whether these mountains bear the marks of two cycles of erosion, separated by a broad uplift with little deformation, as is believed by Brückner and Machatschek; and if so, what stages of erosion were reached in each cycle. The occurrence of several reduced or truncated anticlines of resistant limestone led us to accept the two cycle theory, and to regard the first cycle as having reached a far advanced stage over large areas, although strong residual reliefs seem to have survived where the strongest limestone anticlines, even if much reduced in mass, rose well above the level of truncation elsewhere detected. The second cycle has already produced old forms in the synclines of weak strata, but the valleys that cut through the strong limestone anticlines are still narrow and young, with abundant rock outcrops and frequent rapids in their streams. This conclusion was reached with some regret, for the Jura Mountains, considered as a one cycle range, had a high pedagogical value. Now that they must be displaced from the elementary position in which they have been long classed, where shall we find a one-cycle mountain range of folded structure with which to 
replace them? It is to be noted, however, that if the Jura mountains are to be regarded as a two-cycle range, the difficulty of accounting for the transverse watergaps or "cluses" through the hard limestone anticlines, is apparently lessened by removing the origin of the transverse streams from the little advanced current cycle to the much farther advanced preceding cycle.

Before entering the Alps we visited, under Dr. Nussbaum's guidance, the hilly piedmont district between Bern and Luzern. The forms here seen were entirely the product of normal erosion; but along the streams our leader pointed out the several terraces which are correlated with the successive glacial epochs of the neighboring Alpine valleys.

Overdeepened Valleys in the Alps.-Our traverse of the Alps from Luzern to Lake Maggiore by way of the Brünig, Grimsel, Furka and St. Gotthard passes, was a memorable experience, even though the walk over the Furka was in clouds and rain. The finest part of this trip was the two-days walk from Meiringen up the Aar valley and over the Grimsel pass to the head of the Rhone. The profound influence of glacial erosion was, to our eyes, indisputable. The heavy limestone sill across the broad trough floor, by which the basin of Innetkirchen is inclosed a short distance above Meiringen, and the narrow slit of the Aar gorge through the sill, were most impressive illustrations of what ice cannot do and what water can do; or, if the reader prefers, of what ice can do and what water can not do. Hanging lateral valleys were too abundant to count. We looked with especial care at the form of the overdeepened trough for a score of miles or more, to determine to what extent its excavation had been preceded by the normal erosion of a sharp trench in the floor of the mature preglacial valley, as suggested by de Martonne; and we were obliged to reject such trenching as an essential precursor to deep glacial erosion of main valleys below side valleys, not merely because we found no signs of it, but because the occurrence of two-storied hanging valleys, of which we saw several examples, is essentially inconsistent with it. By two-story hanging valleys, we mean lofty branch valleys which hang over middle-height side valleys, which in turn hang above overdeepened main valleys; all these valleys having the well-defined trough form that is indicative of strong glacial erosion. The occurrence of two-story hanging valleys demands strong erosive power on the part of the mid-height side glacier, independent of any gorge that may be supposed to have been trenched in the floor of the main valley in immediately preglacial time; and if we are obliged to attribute strong erosive power to medium-sized side glaciers, we 
must attribute still greater erosive power to the main glacier, which therefore can have excavated its great overdeepened trough about as easily without as with the aid of a preparatory gorge of normal erosion.

It is perhaps true that, as de Martonne urges, the preparatory erosion of a normal gorge in the floor of a mature valley would facilitate the excavation of an overdeepened trough by glacial erosion; but even if so, it does not follow that this favorable condition was presented. The ancient glaciers may have had to do their work under conditions less favorable than the best. A more general objection to the idea that preglacial gorges are necessary aids to the glacial overdeepening of main valleys is found in the widespread occurrence

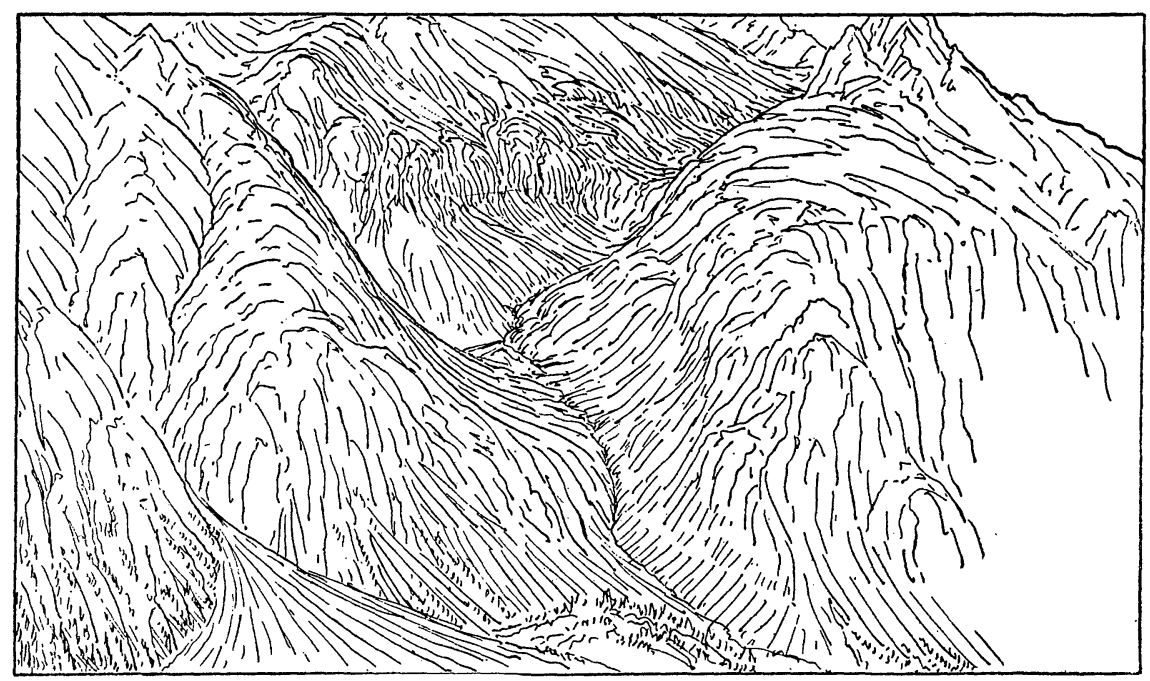

FIG. 10.-Diagram from a rough sketch of a two-story hanging valley on the west side of the Aar valley, near Handeck on the road over the Grismsel pass; looking northwest.

of mountain ranges in which the various features resulting from strong. glacial erosion are easily recognized. If the production of these features by glacial erosion was dependent upon the preparatory erosion of narrow gorges in mature valleys in immediately preglacial time, we should then have to postulate a revival of normal erosion in all formerly glaciated mountains shortly before their glaciation took place. While this is not impossible, it is so special a condition that it is extremely improbable. To assume it would embarrass more than it would aid the theory of glacial erosion.

Close attention was furthermore given in the Aar valley to the occurrence of benches on the valley sides, from which successive 
epochs of glacial overdeepening have been inferred by some observers. Various opinions were held on this point by different pilgrims. For my own part, while it was easy to recognize one great trough of somewhat irregular or immature form, excavated beneath the higher mountain slopes, and while it was easy to see changes of slope in many profiles of the trough walls, the benches thus indicated were too illdefined, too irregular, and too discontinous to be accepted as proving the glacial excavation of a sucession of troughs of smaller and smaller size to greater and greater depths.

LaKe MagGIore. - Our walk from Hospental over the St. Gotthard pass and thence down the valley of the Ticino, with several long lifts

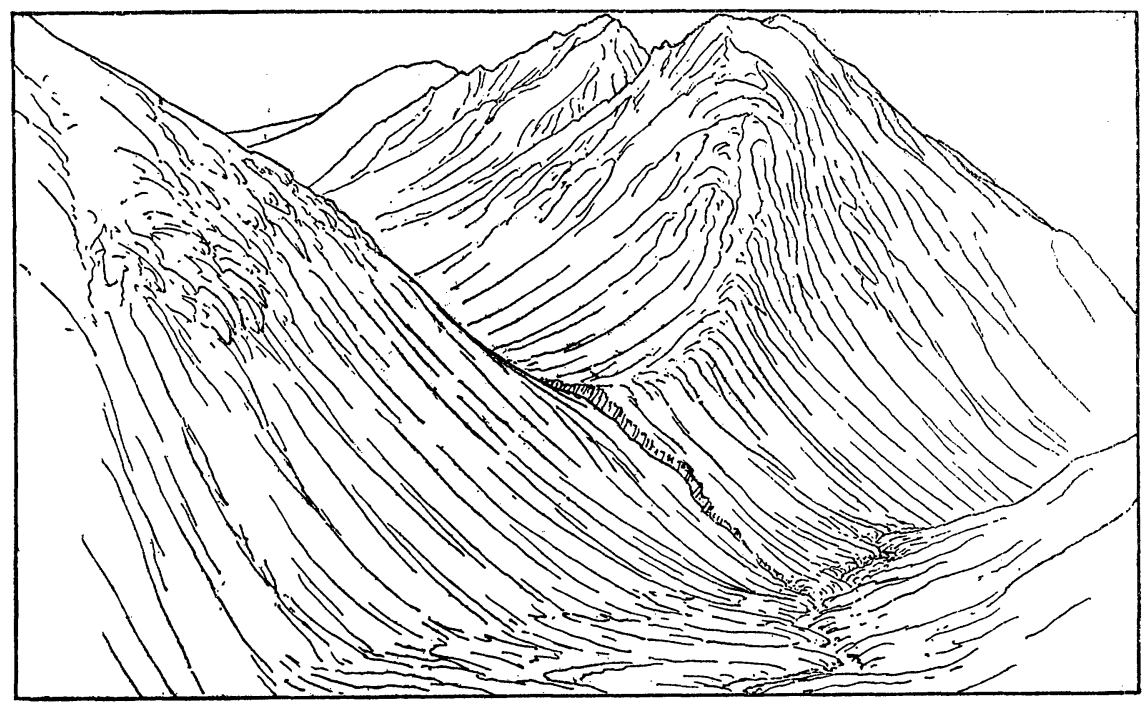

FIG. 11.-The Guspistal, a well defined hanging valley south of Hospental, as seen from road over the St. Gotthard pass; looking southeast.

by train, only confirmed the impressions gained in the valley of the Aar. The valley of the Ticino and its extension in the basin of Lake Maggiore can be confidently recommended to any observer, already familiar with mountains and valleys of normal erosion, who wishes to find conclusive evidence by which to settle the question of glacial erosion. Hanging lateral valleys abound in the mountain slopes above the lake waters, as well as farther up the Ticino. Moreover, we now have for the valley Lautensach's thesis, "Die Uebertiefung des Tessingebietes." 3 For the lake there is no detailed description which

\footnotetext{
${ }^{8}$ Penck's Geogr. Abhandl., Berlin, 1912.
} 
discusses in sufficient detail the smoothness of the trough at and below the lake level, and the countless normal valleys by which the trough sides are dissected above the lake level. It was interesting to find on the Italian maps of the lake that its western arm, where a large branch glacier came down from the Simplon pass, is of much less depth than its main trough, and that there appears to be an abrupt increase of depth where one joins the other, as if the western arm were a submerged hanging valley.

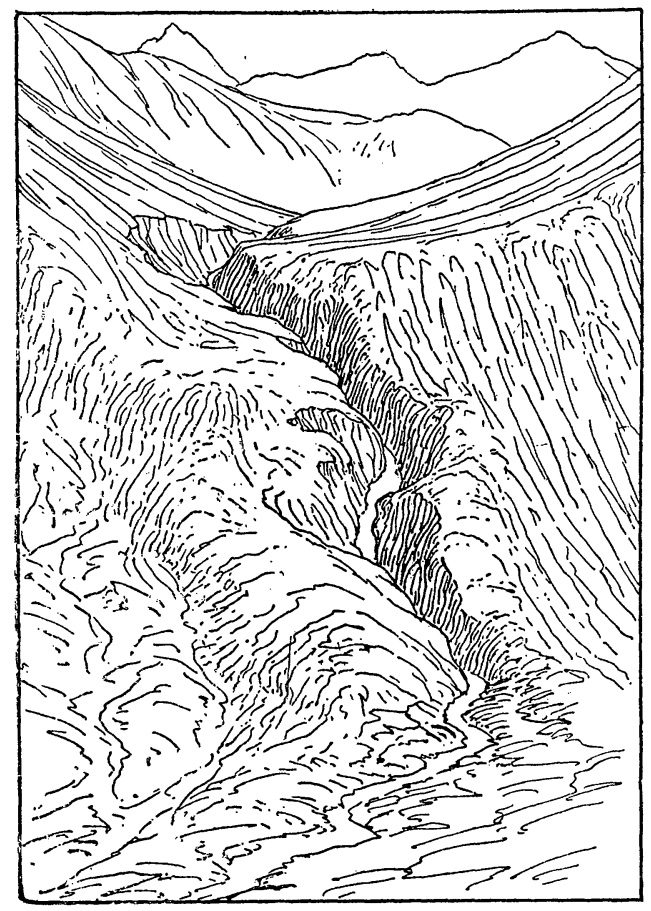

FrG. 12.-Front view of the Guspistal, showing the connecting gorge; looking east.

We were joined at the head of this beautiful lake by Professors Olinto Marinelli of Florence and Guiseppi Ricchieri of Milan, who then acted as our guides until the party broke up at Lugano a few days later. We had their pleasant company during an ascent by inclined railway of Monte Mottarone next south of the west arm of Maggiore, and during a delightful afternoon in a morainic amphitheater formed by an out-going branch of the Ticino-Maggiore glacier which excavated the small distributary basin of Lake Varese, a typical example of its kind in a densely populated and closely cultivated district of great scenic beauty. The party disbanded at Lugano. 